\title{
Evaluation of Fatigue Behavior in Dental Implants from In Vitro Clinical Tests: A Systematic Review
}

\author{
Rosa Rojo ${ }^{1, *,+(\mathbb{C}) \text {, María Prados-Privado }}{ }^{2,3,+}$, Antonio José Reinoso ${ }^{4}$ and \\ Juan Carlos Prados-Frutos 1 \\ 1 Department of Medicine and Surgery, Faculty of Health Sciences, Rey Juan Carlos University, \\ 28922 Alcorcon, Spain; juancarlos.prados@urjc.es \\ 2 Department Continuum Mechanics and Structural Analysis Higher Polytechnic School, Carlos III University, \\ 28911 Leganes, Spain; mprados@ing.uc3m.es \\ 3 Asisa Dental (Engineering Researcher), José Abascal 32, 28003 Madrid, Spain \\ 4 Department of ICT Engineering, Alfonso X El Sabio University, 28691 Madrid, Spain; areinpei@myuax.com \\ * Correspondence: rosa.rojo@urjc.es; Tel.: +34-914-888-817 \\ + These authors contributed equally to this work.
}

Received: 18 March 2018; Accepted: 26 April 2018; Published: 3 May 2018

check for updates

\begin{abstract}
In the area of dentistry, there is a wide variety of designs of dental implant and materials, especially titanium, which aims to avoid failures and increase their clinical durability. The purpose of this review was to evaluate fatigue behavior in different connections and implant materials, as well as their loading conditions and response to failure. In vitro tests under normal and dynamic loading conditions evaluating fatigue at implant and abutment connection were included. A search was conducted in PubMed, Scopus, and Science Direct. Data extraction was performed independently by two reviewers. The quality of selected studies was assessed using the Cochrane Handbook proposed by the tool for clinical trials. Nineteen studies were included. Fourteen studies had an unclear risk and five had high risk of bias. Due to the heterogeneity of the data and the evaluation of the quality of the studies, meta-analysis could not be performed. Evidence from this study suggests that both internal and morse taper connections presented a better behavior to failure. However, it is necessary to unify criteria in the methodological design of in vitro studies, following methodological guidelines and establishing conditions that allow the homogenization of designs in ISO (International Organization for Standardization) standards.
\end{abstract}

Keywords: biomechanics; dental implant(s); in vitro; systematic reviews; evidence-based medicine

\section{Introduction}

The use of dental implants has become a common practice for replacing missing teeth in different clinical situations [1,2]. The used materials are chosen according to both their mechanical and chemical properties, as well as to their biocompatibility [3]. Commercially, pure titanium and its alloys are widely used for manufacturing dental implants because of excellent mechanical and physical properties, and favorable rates for long-term clinical survival [4]. In addition, titanium-based implants have a good resistance to corrosion with an excellent biocompatibility and high modulus of elasticity $[5,6]$. The use of Ti-6Al-4V [7] alloy is employed for biomedical application and, also, in dental implants due to its high mechanical resistance, which ensures load transmission to bone tissues over a long time, which is necessary when damaged hard tissues are replaced by prostheses [3]. This alloy presents a drawback due to the use of vanadium and aluminum that can cause some toxic effects. Other titanium grades can be employed in dental implants but they also have disadvantages like the Young modulus, relatively low mechanical strength, poor wear resistance and difficulty to improve the mechanical 
properties without reducing biocompatibility. New $\beta$-type titanium alloys for dental implants have been developed. These have good properties and less toxicity, good ductility, high resistance. They also have elastic modules closer to those of human bone compared to other alloys [7].

Although the mechanical strength of dental implants is important, they must also present adequate stiffness to avoid shielding the bones from stress. This stress shielding induces loss of bone density, leading to bone atrophy. Moreover, the interaction between titanium and tissues is a key factor in the success of dental implants and, for this reason, surfaces of used alloys are conveniently treated. If the implant is manufactured with titanium grade 5 , those implants must have a surface treatment to improve the corrosion [3]. This interaction between titanium and tissues is affected by the implant surface composition, as well as by its hydrophilicity, morphology, and roughness [8]. Different surface treatments have been tried and developed with the aim of obtaining titanium surfaces with better biological properties. This surface treatment yields a good osseointegration and obtain an improvement on the success of dental implants [9] with a change in the chemical composition. Nano roughness, texture, and porosity are some of the most important factors in the surface of an implant because they affect the ability of cells to adhere to a solid substrate [10].

The manufacturing process also influences the alloy's characteristics. The tensile strength of titanium alloy can range from 369 to $3267 \mathrm{MPa}$ depending on the process employed. Fatigue behavior is also affected by the manufacturing process and it can be also improved by combining the material properties, surface properties, and design optimization of implants.

Despite all the advantages of titanium, considered as the "gold standard" material for the manufacture of dental implants, its biggest drawback are aesthetic considerations. Therefore, manufacturers began to use other types of materials such as ceramics $[4,11]$ or polymers [4].

Osseointegrated dental implants are described in detail in a great number of studies [12], although implant-supported connection have been less disclosed in the literature [13].

Nowadays, a vast number of implant designs are available. The first dental implants had an external connection, where the hexagonal anti-rotational component is the most common design. Figure 1a shows an example of this connection. Due to the high rate of rejected implants, a new connection was designed. In this case, internal connection (Figure 1b) allowed a better union between the implant and the abutment. Finally, morse taper connection (Figure 1c), which is another option for an internal connection, was introduced because of its improvement on screw loosening [14-16].

These designs are different in terms of the connection of the implant-abutment (external or internal connections) $[17,18]$, which from a mechanical point of view, is the weakest area of the implant system [19].

Applying static load tests to evaluate the strength of the implants and their components is a common practice. However, these tests do not simulate real situations for implants [2]. Considering that masticatory forces are cyclic, a fatigue testing should be carried out to predict how long an implant system is going to function properly [20]. In vitro tests should better simulate the clinical situations [21-23] and allow clinicians to understand the probability of survival of prosthetic components and implants [13]. Before implant components are launched to the market, they should satisfy the ISO 14801 specifications [24]. This ISO recommendation was planned for single, endosteal, transmucosal dental implants tested under worst case applications. Nevertheless, several testing protocols for evaluating the mechanical reliability of dental implants are available in the literature [25]. Different loading angles, frequency of loads, and application load levels have been employed in several published cyclic testing protocols [26].

The fracture of an implant or of any of its components is an important complication which limits the lifetime of the reconstruction. Although most of the studies available are limited to 5-7 years of follow-up [26], Snauwaert et al. found in a 15-year study, an early implant fracture (up to one year after abutment connection) in 3.4\% and late implant failures of 7.4\% [27]. Considering that implants should serve for decades, these type of studies are inadequate to analyze implant failure or fracture 
and make essential to examine dental implants under fatigue testing approaches. Once the number of cycles an implant can support until failure are known, its expected life can be predicted accurately [28].

The aim of this systematic review was to evaluate fatigue behavior in different connections and types of implants, their loading conditions, and their response to failure between implant and abutment.
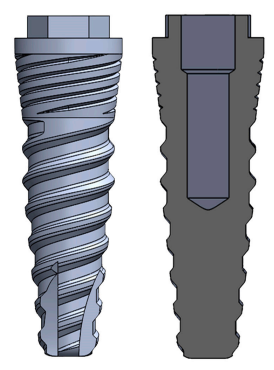

(a)

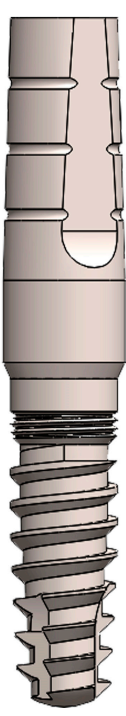

(b)

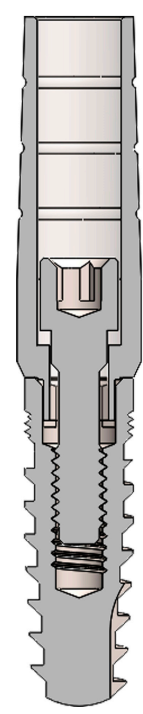

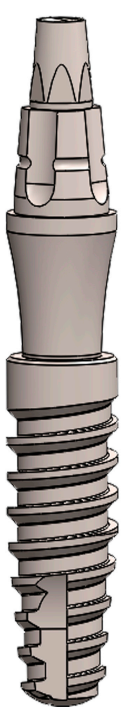

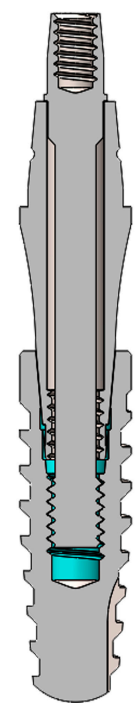

(c)

Figure 1. Schematic views of dental implant connections: (a) External connection (b) Internal connection (c) Morse taper connection.

\section{Materials and Methods}

This systematic review follows the Preferred Reporting Items for Systematic Reviews and Meta-Analyses (PRISMA) guidelines [29].

\subsection{Focused Questions}

First question (A): Does a certain number of cycles and a certain force (Newtons) exist between a defined implant connection and abutment failure?

Second question (B): How many cycles does a certain implant connection and abutment fail?

\subsection{Inclusion and Exclusion Criteria}

Inclusion criteria were in vitro clinical studies on dental implants in which fatigue at the implant and abutment connection were evaluated by subjecting them to dynamic cyclic loads. Studies were been carried out under normal environmental conditions. Dental implants are included disregarding the type of connection. There were no restrictions on the language or date of publication.

Exclusion criteria were all designs of observational studies, reviews, thermal fatigue assessment, static tests, or using incorrect units of measure.

\subsection{Search Strategy}

In this paper the research questions were elaborated considering each of the components of the $\mathrm{PICO}(\mathrm{S})[30]$ strategy research questions which is explained as follows: $(\mathrm{P})$ dental implants and abutments; (I) cyclic loads; (C) studies with or without a comparison group where external, internal or morse taper connections were evaluated with implant materials and/or abutment of titanium, zirconium or others; (O) the evaluation of fatigue in terms of failure; (S) in vitro study. 
An electronic search was performed in MEDLINE/PubMed, Scopus and Science Direct, database until the 15 March 2018. The search strategy used is detailed in Table 1.

Table 1. Search strategies carried out in databases.

\begin{tabular}{|c|c|c|}
\hline Database & Search Strategy & Search Data \\
\hline MEDLINE/PubMed & $\begin{array}{l}\text { (dental AND (implant OR abutment) OR tooth implant) } \\
\text { AND (cyclic loading) AND ((internal OR external) } \\
\text { connection) AND (fatigue OR moment OR stress) AND } \\
\text { ("in vitro" OR “experimental study") NOT (review) }\end{array}$ & 15 March 2018 \\
\hline Scopus & $\begin{array}{l}\text { (dental AND (implant OR abutment) OR tooth implant) } \\
\text { AND (cyclic loading) AND ((internal OR external) } \\
\text { connection) AND (fatigue OR moment OR stress) AND } \\
\text { ("in vitro" OR "experimental study") AND NOT (review) }\end{array}$ & 15 March 2018 \\
\hline Science Direct & $\begin{array}{l}\text { (dental AND (implant OR abutment) OR tooth implant) } \\
\text { AND (cyclic loading) AND ((internal OR external) } \\
\text { connection) AND (fatigue OR moment OR stress) AND } \\
\text { ("in vitro" OR "experimental study") AND NOT (review) }\end{array}$ & 15 March 2018 \\
\hline
\end{tabular}

\subsection{Study Selection}

Two authors (Rosa Rojo and María Prados-Privado) performed all the search operations and selected articles fulfilling the inclusion criteria independently and in duplicate. Additionally, the references of the articles included in this work were manually reviewed. Disagreements between the two authors were reviewed in a complete text by a third author (Juan Carlos Prados-Frutos) to make the final decision. The level of agreement between the reviewers regarding study inclusion was calculated using Cohen's kappa statistic.

\subsection{Data Extraction}

Two of the authors (María Prados-Privado and Rosa Rojo) collected all the data from the selected articles in duplicate and independently.

\subsection{Study Quality Assessment}

The assessment of risk of bias from clinical in vitro studies was evaluated by two of the authors (María Prados-Privado and Antonio José Reinoso), who were previously trained by an expert in evaluation of systematic reviews. For the assessment of risk of bias the Cochrane Handbook [31] was followed which incorporates seven domains: random sequence generation (selection bias); allocation concealment (selection bias); masking of participants and personnel (performance bias); masking of outcome assessment (detection bias); incomplete outcome data (attrition bias); selective reporting (reporting bias); and other bias.

The articles that did not achieve consensus between the two authors were reviewed by a third author (Rosa Rojo) to make the final decision.

The studies were classified into the following categories: low risk of bias-low risk of bias for all key domains; unclear risk of bias-unclear risk of bias for one or more key domains; high risk of bias-high risk of bias for one or more key domains.

\subsection{Statistical Analysis}

To evaluate the agreement between the inter-examiner, the statistic Cohen's kappa and the interpretation proposed by Landis \& Koch [32] was used. Statistical calculations were performed with R software version 3.4.1 (R Core Development Team, R Foundation, Vienna, Austria) with the interrater reliability (irr) package. 


\section{Results}

\subsection{Study Selection}

Figure 2 shows a flowchart of the study selection. All electronic search strategies provided 161 potential articles. Two of the authors (Rosa Rojo and María Prados-Privado) independently identified 48 eligible documents. The general agreement of eligibility of the studies between the authors was high $(k=0.87 ; p=0.049$.) Specifically, agreement between authors on the selection of articles in each considered database was high for all of them: Medline/PubMed $(k=0.93 ; p=0.046)$, Scopus $(k=0.80 ; p=0.043)$, and Science Direct $(k=0.82 ; p=0.05)$. A total of 38 studies were excluded because they did not meet the defined inclusion criteria. Additionally, a manual search has been carried out to analyze the references cited in 10 of the articles that were included in this work. We reviewed 342 references. After removing duplicates, we analyzed the titles, abstracts and, when required, the full-text from 272 citations. A total of 263 studies were excluded as they did not match the inclusion criteria. As a result, nine additional articles were incorporated from the manual search. Finally, a total of nineteen in vitro studies were analyzed.

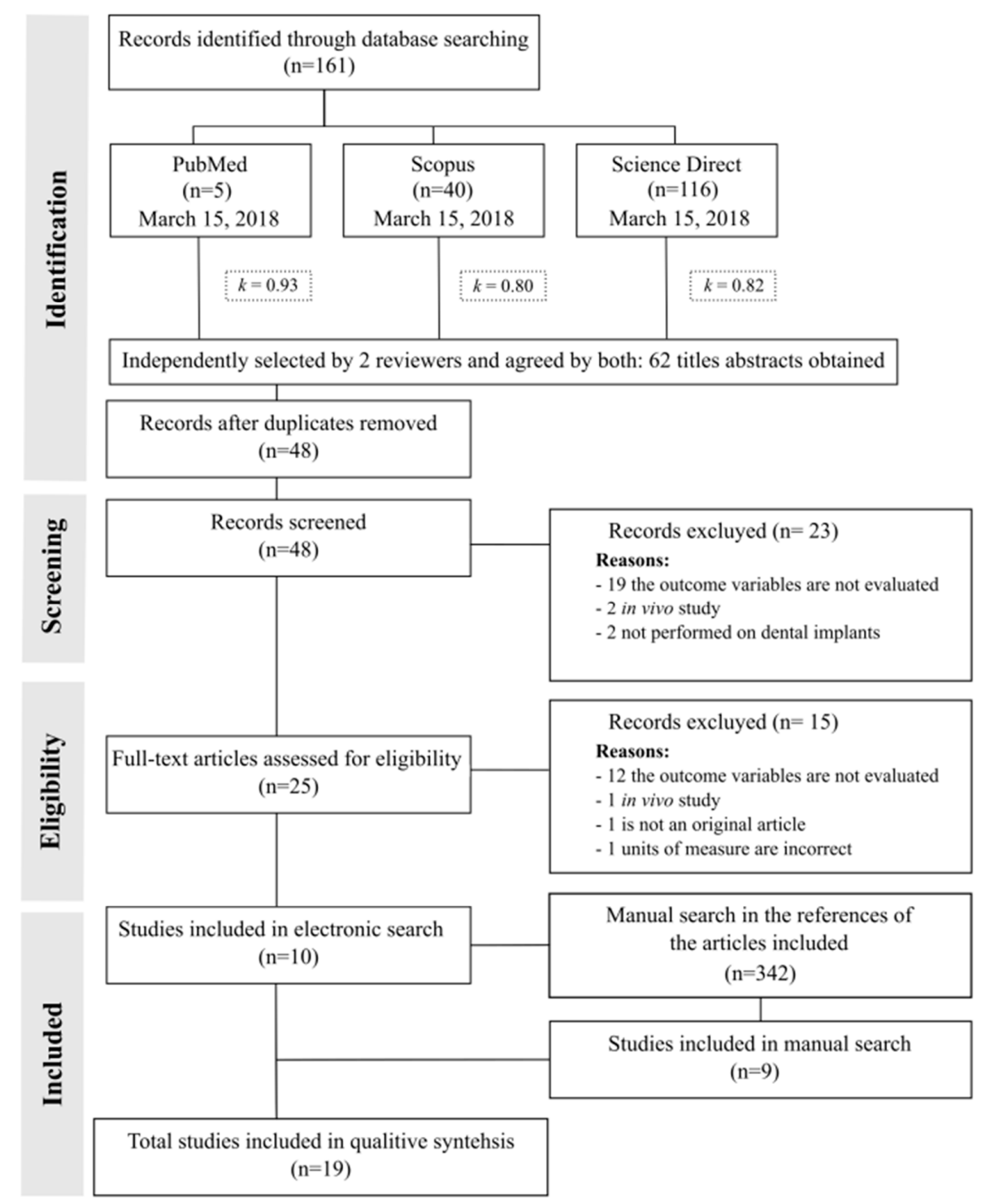

Figure 2. Flow chart. 


\subsection{Relevant Data from Studies}

Two of the authors (María Prados-Privado and Rosa Rojo) extracted all the data from the selected works whose characteristics are shown in Table 2 . The 19 in vitro studies analyzed [20,33-50] were carried out in several countries: Japan, Italy, Germany, Australia, Brazil, Switzerland, Turkey, Republic of Singapore, Greece, and the United States.

For all the studies, we collected the most important variables that could affect the results, such as sample size, the existence of funding, main characteristic of dental implants (connection, material, diameter and length), main properties of abutments (material and length), and applied load (magnitude, angulation, frequency and cycles).

Table 3 shows the 14 studies that answered the first question (A). The best behavior analyzed corresponded to a study where the zirconium-based implant hardened with alumina-doped yttrium-stabilized yttrium zirconium polyurethane and abutment of the same material was applied with a force of $98 \mathrm{~N}$ to $10,000,000$ cycles [48]. No fault displayed.

Moreover, were are studies where the zirconium-based implant and abutment with an applied force of $50 \mathrm{~N}$ at $100 \mathrm{~N}, 45^{\circ}$ of the axial axis of the dental implant and from 1,200,000 [46] to 3,600,000 cycles [50], respectively, showed failure under similar conditions.

It was observed that the titanium had a better behavior if the implant and the abutment were made of the same material $[42,44,46,50]$. The results also suggest that the behavior of the titanium worsens when the materials of the implant and the abutment are different $[20,36,38]$.

Table 4 shows the six studies that answer the second question (B). The maximum number of reported cycles where the connection between the implant and the pillar fails is 5,000,000 cycles $[33,41,45]$. From the studies presenting better behavior fatigues, it has been found that the implant and the abutment are both made from titanium [33,45], or the abutment is combated with zirconium [41].

For both questions, Tables 3 and 4 show that the implant and the abutment behave better in the internal connections $[33,41-46,48,50]$ and morse taper $[41,47,49]$. The study conducted by Mitsias et al. [47] answers the two research questions addressed in this work.

\subsection{Study Quality Assessment}

Evaluation of selection bias: They were only included in two of the analyzed studies of the method of randomization used $[43,45]$. However, it does not indicate whether there was concealment of this allocation.

Evaluation of performance bias: In all the studies analyzed there was no blinding of staff or assessors. Moreover, we found that in [34] the evaluator who prepared the specimens and who performed the tests were the same person. This fact may lead to a high risk of bias.

Assessment of detection bias: The results were not blinded in any of the studies.

Evaluation of attrition bias: All studies reported the complete results of the specimens defined in the clinical trial, although some reported inaccurately without indicating in the results the variable descriptions in their methodology [39,42].

Evaluation of notification bias: All studies provide detailed results with the exception of one, this study did not describe correctly whether the variables are quantitative or qualitative [39].

Evaluation of other bias: Funding was considered as another possible risk of bias in study designs. Eleven trials were funded by commercial firms [20,35,36,40-43,46,48-50], five were not reported [33,34,37,38,44], and three reported that no funding existed [39,45,47].

Using the evaluation of the seven domains for risk of bias it was determined that five had a high risk of bias [20,33-36], 14 an unclear risk [37-50], and none had a low risk of bias. Figure 3 shows a detailed description of the risk assessment of bias in the included studies. 
Table 2. Main characteristics of the included studies.

\begin{tabular}{|c|c|c|c|c|c|}
\hline Author/Year & Country & Journal & $\mathbf{n}$ & G & Financing \\
\hline Balfour et al. [33] 1995 & United States & Journal of Prosthetic Dentistry & 21 & 3 & $\mathrm{U}$ \\
\hline Khraisat et al. [34] 2002 & Japan & Journal of Prosthetic Dentistry & 14 & 2 & $\mathrm{U}$ \\
\hline Çehreli et al. [35] 2004 & Turkey & Clinical Oral Implants Research & 8 & 1 & $\mathrm{Y}$ \\
\hline Butz et al. [36] 2005 & United States & Journal of Oral Rehabilitation & 48 & 3 & Y \\
\hline Gehrke et al. [37] 2006 & Germany & Quintessence International & 7 & 1 & $\mathrm{U}$ \\
\hline Kohal et al. [38] 2009 & Germany & Clinical Implant Dentistry and Related Research, & 48 & 3 & $\mathrm{U}$ \\
\hline Scarano et al. [39] 2010 & Italy & Italian Oral Surgery & 20 & 1 & $\mathrm{~N}$ \\
\hline Magne et al. [40] 2011 & Switzerland & Clinical Oral Implants Research & 28 & 2 & Y \\
\hline Seetoh et al. [41] 2011 & Republic of Singapore & The International Journal of Oral \& Maxillofacial Implants & 30 & 6 & Y \\
\hline Dittmer et al. [20] 2012 & Germany & Journal of Prosthodontic Research & 60 & 2 & $\mathrm{Y}$ \\
\hline Stimmelmayr et al. [42] 2012 & Germany & Dental Materials & 6 & 2 & Y \\
\hline Foong et al. [43] 2013 & Australia & Journal of Prosthetic Dentistry & 22 & 2 & $\mathrm{Y}$ \\
\hline Pintinha et al. [44] 2013 & Brazil & Journal of Prosthetic Dentistry & 48 & 2 & $\mathrm{U}$ \\
\hline Marchetti et al. [45] 2014 & Italy & Implant Dentistry & 15 & 2 & $\mathrm{~N}$ \\
\hline Rosentritt et al. [46] 2014 & Germany & Journal of Dentistry & 64 & 8 & $\mathrm{Y}$ \\
\hline Mitsias et al. [47] 2015 & Greece & The International Journal of Prosthodontics & 36 & 2 & $\mathrm{~N}$ \\
\hline Spies et al. [48] 2016 & Germany & Journal of the Mechanical Behavior of Biomedical Materials & 48 & 3 & $\mathrm{Y}$ \\
\hline Guilherme et al. [49] 2016 & United States & Journal of Prosthetic Dentistry & 57 & 3 & $\mathrm{Y}$ \\
\hline Preis et al. [50] 2016 & Germany & Dental Materials & 60 & 6 & Y \\
\hline
\end{tabular}

n: sample size; G: Number of groups; Y: Yes; N: No; U: Unclear.

Table 3. Variables analyzed from the answer to question A.

\begin{tabular}{|c|c|c|c|c|c|c|c|c|c|c|c|}
\hline \multirow{2}{*}{ Author/Year } & \multicolumn{4}{|c|}{ Implant } & \multicolumn{2}{|c|}{ Abutment } & \multicolumn{3}{|c|}{ Applied Load } & \multirow{2}{*}{ Cycles } & \multirow{2}{*}{ Failure } \\
\hline & Connection & Material & Diameter & Length & Material & Length & Magnitude (N) & Angulation $\left({ }^{\circ}\right)$ & Frequency $(\mathrm{Hz})$ & & \\
\hline Çehreli et al. [35] 2004 & - & - & 10 & - & - & - & $75 \pm 5$ & 20 & 0.5 & 500,000 & $\mathrm{~N}$ \\
\hline \multirow{2}{*}{ Butz et al. [36] 2005} & $\mathrm{E}$ & - & 4 & 13 & $\mathrm{Ti}$ & - & 30 & 130 & 1.3 & $1,200,000$ & $\mathrm{Y}$ \\
\hline & - & - & 4 & 13 & $\mathrm{Ti}$ & - & 30 & 130 & 1.3 & $1,200,000$ & $\mathrm{Y}$ \\
\hline \multirow{3}{*}{ Gehrke et al. [37] 2006} & I & - & 4.5 & 18 & $\mathrm{Zi}$ & - & $100-450$ & - & 15 & $5,000,000$ & $\mathrm{Y}$ \\
\hline & $\mathrm{I}$ & - & 4.5 & 18 & $\mathrm{Zi}$ & - & $100-450$ & - & 15 & $5,000,000$ & $\mathrm{Y}$ \\
\hline & I & - & 4.5 & 18 & $\mathrm{Zi}$ & - & $100-450$ & - & 15 & $5,000,000$ & $\mathrm{Y}$ \\
\hline \multirow[t]{2}{*}{ Kohal et al. [38] 2009} & $\mathrm{M}$ & $\mathrm{Zr}$ & - & - & $\mathrm{Zi}$ & - & 45 & - & - & $1,200,000$ & $\mathrm{Y}$ \\
\hline & $\mathrm{M}$ & $\mathrm{Ti}$ & - & - & $\mathrm{P}$ & - & 45 & - & - & $1,200,000$ & $\mathrm{Y}$ \\
\hline Scarano et al. [39] 2010 & $\mathrm{M}$ & $\mathrm{Ti}$ & 4 & 13 & - & - & $5-230$ & 30 & 4 & $1,000,000$ & $\mathrm{~N}$ \\
\hline
\end{tabular}


Table 3. Cont

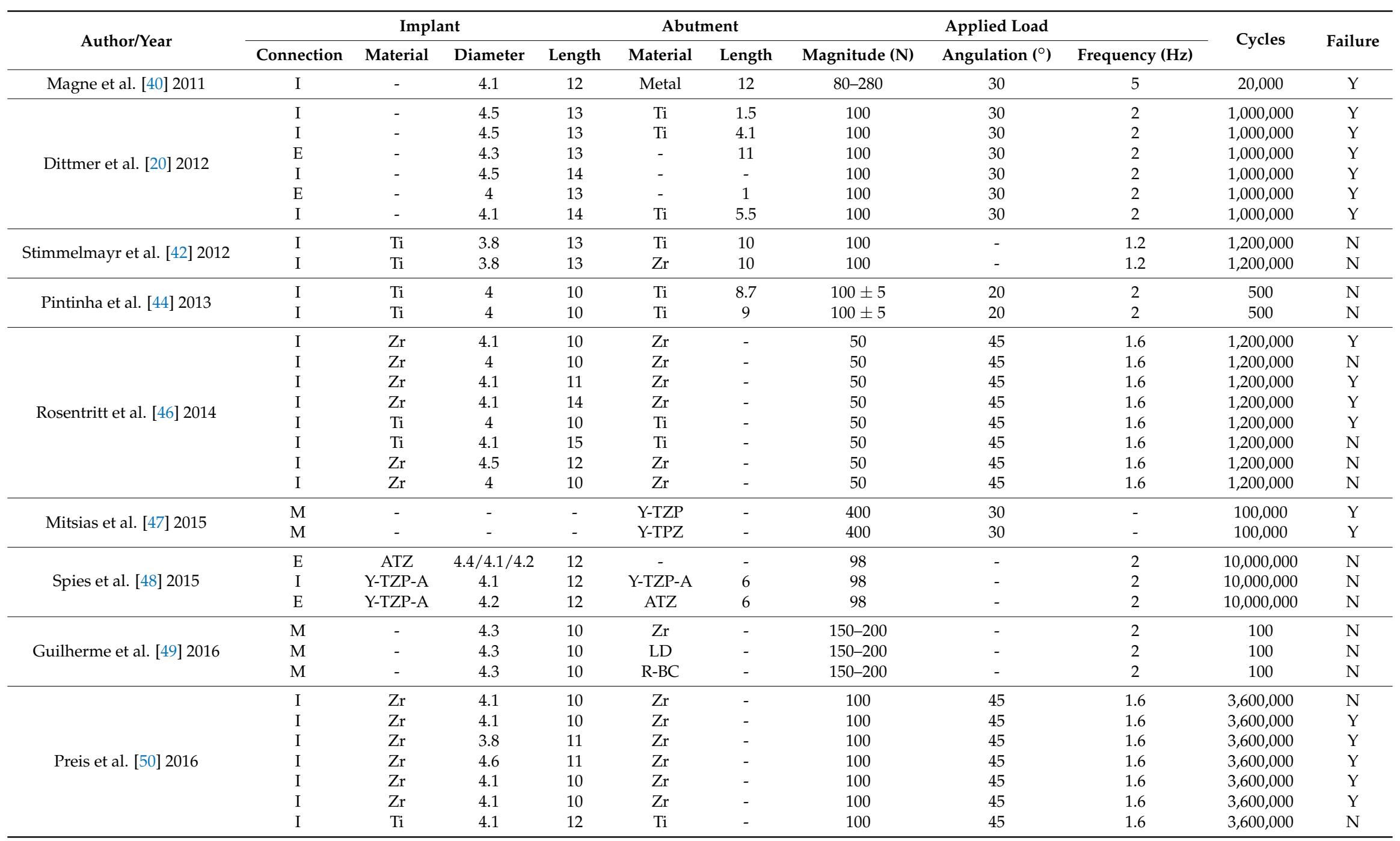

I: Internal connection; E: external connection; M; morse taper connection; Ti: Titanium; Zr: Zirconia; ATZ: alumina-toughened zirconia; Y-TZP-A: yttrium stabilized tetragonal zirconium dioxide polycrystal doped with alumina; LD: lithium disilicate; R-BC: resin-based composite; Y: Yes; N: No; -: No data. 
Table 4. Variables analyzed from the answer to question B.

\begin{tabular}{|c|c|c|c|c|c|c|c|c|c|c|c|}
\hline \multirow{2}{*}{ Author/Year } & \multicolumn{4}{|c|}{ Implant } & \multicolumn{2}{|c|}{ Abutment } & \multicolumn{3}{|c|}{ Applied Load } & \multirow{2}{*}{ Cycles } & \multirow{2}{*}{ Failure } \\
\hline & Connection & Material & Diameter & Length & Material & Length & Magnitude & Angulation & Frequency & & \\
\hline \multirow{3}{*}{ Balfour et al. [33] 1995} & $E$ & $\mathrm{Ti}$ & - & - & $\mathrm{Ti}$ & - & 242 & 30 & 14 & $5,000,000$ & $\mathrm{Y}$ \\
\hline & I & $\mathrm{Ti}$ & - & - & $\mathrm{Ti}$ & - & 400 & 30 & 14 & $5,000,000$ & Y \\
\hline & I & $\mathrm{Ti}$ & - & - & $\mathrm{Ti}$ & - & 367 & 30 & 14 & $5,000,000$ & Y \\
\hline \multirow{2}{*}{ Khraisat et al. [34] 2002} & $\mathrm{E}$ & $\mathrm{Ti}$ & 4 & 10 & $\mathrm{Ti}$ & 3 & 100 & 90 & 1,25 & $1,800,000$ & $\begin{array}{c}\mathrm{Y}(1,178,023 \text { and } \\
1,733,526)\end{array}$ \\
\hline & M & $\mathrm{Ti}$ & 4.1 & 10 & $\mathrm{Ti}$ & 10 & 100 & 90 & 1,25 & $1,800,000$ & $\mathrm{Y}($ more $1,800,000)$ \\
\hline \multirow{2}{*}{ Seetoh et al. [41] 2011} & $\mathrm{M}$ & - & 4.5 & 15 & $\mathrm{Zr} / \mathrm{Ti}$ & - & 21 & 45 & 10 & $5,000,000$ & $\mathrm{Y}$ \\
\hline & M & - & 4.1 & 14 & $\mathrm{Zr} / \mathrm{Ti}$ & - & 21 & 45 & 10 & $5,000,000$ & Y \\
\hline \multirow{2}{*}{ Foong et al. [43] 2013} & I & $\mathrm{Ti}$ & 4 & 9 & $\mathrm{Ti}$ & 1.5 & $50-400$ & 30 & 2 to 5 & $5,000-20,000$ & $\mathrm{Y}($ mean of 81,935$)$ \\
\hline & I & $\mathrm{Ti}$ & 4 & 9 & $\mathrm{Zr}$ & 1.5 & $50-400$ & 30 & 2 to 5 & $5,000-20,000$ & $Y($ mean of 26,926$)$ \\
\hline \multirow{2}{*}{ Marchetti et al. [45] 2014} & I & $\mathrm{Ti}$ & 3.8 & 13 & $\mathrm{Ti}$ & - & 400 & $30 \pm 2$ & 15 & $5,000,000$ & $\mathrm{Y}(12,678$ and 15,387$)$ \\
\hline & I & $\mathrm{Ti}$ & 3.8 & 13 & $\mathrm{Ti}$ & - & 300 & $30 \pm 2$ & 15 & $5,000,000$ & $\mathrm{Y}($ more 27,732$)$ \\
\hline \multirow{2}{*}{ Mitsias et al. [47] 2015} & M & - & - & - & Y-TZP & - & 400 & 30 & - & 100,000 & Y (less than 50,000$)$ \\
\hline & $\mathrm{M}$ & - & - & - & Y-TPZ & - & 400 & 30 & - & 100,000 & $Y($ less than 50,000$)$ \\
\hline
\end{tabular}

I: Internal connection; E: external connection; M; morse taper connection; Ti: Titanium; Zr: Zirconia; Y: Yes; N: No; -: No data. 


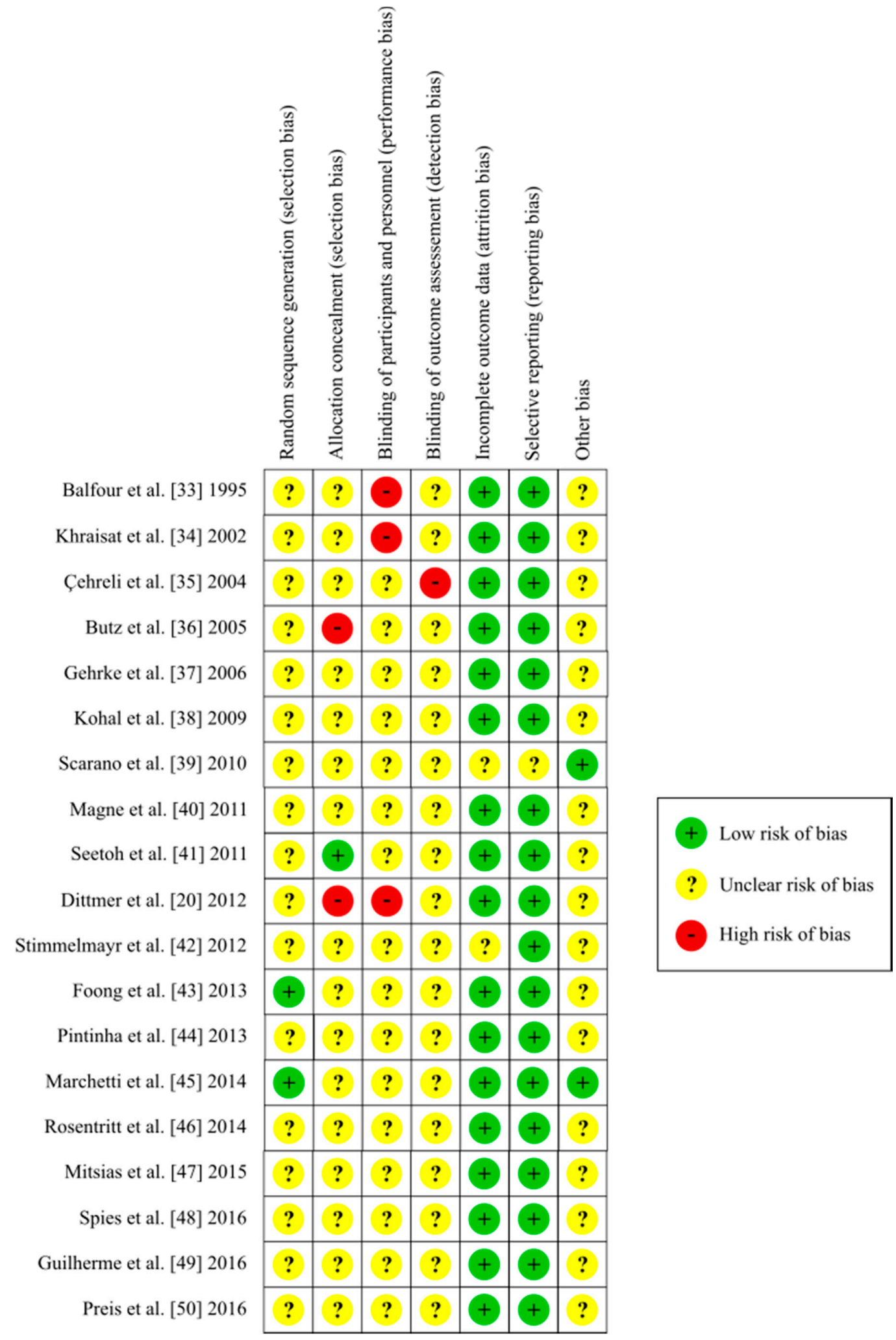

Figure 3. Assessment of risk of bias of included studies.

\section{Discussion}

There are several factors that influence the behavior of dental implants such as the biological effects of the location and magnitude of applied force [51], occlusal forces following implant treatment [52], 
immediate or early implant loading [53], the influence of bone quality, effects of prosthesis type, prosthesis material, or implant support [51].

The clinical long-term success of restorations in oral implantology depends, among other factors on the stable connection between the dental implant and the abutment [54]. Therefore, a good knowledge of the biomechanical behavior of dental implants is essential for clinical decision making and thus, avoid mechanical failures. These are mainly due to fatigue caused by overload or loss of bone around the implant [55-57].

The most common connections between the implant and the prosthesis are the external, internal hexagon and morse taper connections [58]. The main advantages of the external connection are the compatibility with a wide variety of implants, its economical price, the long-term follow-up data available, and the literature provides solutions to the main drawbacks associated with its use. However, among the main disadvantages of this connection are the loosening of the screws, the possibility of screw fracture, worse aesthetic results, and an inadequate microbial seal [59-61].

The appearance of the internal connections was due to the interest in trying to reduce the aesthetic and microbial filtration problems of the external connection, while improving the behavior of the implant and peri-implant bone against masticatory forces [60]. The main advantages of these internal connections are less or no screw loosening, less risk of screw fracture, aesthetic improvement, microbial sealing, and the stability of the implant-prosthesis connection. Among the disadvantages are a higher economic cost and long-term monitoring data lower than the external connection [59,62].

In the morse taper connections, all the components that make up the implantoprosthesis assembly behave as a single whole, the forces are adequately distributed, the stability of the prosthesis is guaranteed, and the areas of greatest mechanical suffering are protected, such as the crestal region of the implant $[17,63]$.

Other factors that influence the fracture of the dental implant are the materials, the diameter and length of the implant, the material and length of the abutment, the applied force, its frequency, and the angulation with respect to the implant [51]. This work includes all the parameters described above even though there is a considerable amount of heterogeneity.

Titanium is still the most used material and it is also supported by long-term clinical studies [4], but also in vitro studies since 1995 [33] introduced zirconium with the gold standard, titanium, to evaluate the fatigue of dental implants. Although the results were favorable, its biggest drawback is its high degree of quality requirement during production and its delicate clinical management [4].

The materials most used for dental implants were titanium and zirconia, with ranges of measures in relation to diameter and height, of $3.8 \mathrm{~mm}$ to $4.6 \mathrm{~mm}$ and $10 \mathrm{~mm}$ to $15 \mathrm{~mm}$, respectively. For the abutment the most used materials were also titanium and zirconia but in the one study [49] also used lithium disilicate and resin-based composite. There is no homogeneous criterion regarding the magnitude, angulation, frequency, and number of cycles applied in the dynamic loads to the implants. Therefore, with the data reported it is not possible to report conclusive results from the different in vitro studies analyzed.

There are several engineering methods to evaluate the fatigue behavior of dental implants such as finite elements [64], mathematical models for probabilistic fatigue [65], or other in vitro studies. These type of study designs have developed, before their use in patients, new materials to understand their physical, chemical, mechanical, and biological properties. These designs can be developed under normal conditions or under other conditions such as in water $[66,67]$ or hydrothermal $[68,69]$ environments.

There is not a large number of studies evaluating fatigue in dental implants in the scientific literature. However, a greater number of in vitro studies which evaluated the same objectives under normal conditions have been addressed. It is therefore desirable to conduct a systematic review.

The main disadvantage of the evaluation of the articles of this work is the high heterogeneity of the confounding factors collected as the different materials, lengths, diameters, or dynamic loading conditions. There is no homogeneity in the design criteria established by each study in this regard. 
With the objective of obtaining more clinically relevant information, future studies should incorporate and analyze the same parameters. Otherwise, there heterogeneity will continue creating doubt in the scientific literature in the field of dentistry [2]. Therefore and, in view of the results obtained in this systematic review, future in vitro analysis should have the same implants dimensions (diameter and length) and cyclic loading conditions (number of cycles, magnitude of force, angle, and medium). The no homogeneity found in these studies contribute to realize that it is necessary to standardize the criteria for carrying out the studies in order to make more concise and reliable comparisons.

Some studies [39,45,46,48,49] use ISO 14801 [24] which specifies the conditions that each type of implant must support to obtain certification. However, these conditions indicate that they should exceed a minimum number of cycles but say nothing about how to conduct experimental studies of implants that are already on the market, and therefore have already been certified.

In systematic reviews, a qualitative analysis of the included studies is required. This is done through the risk assessment of bias. This ensures that the data collected and analyzed have been managed in a controlled manner, avoiding all possible methodological errors in clinical trials. When the data are homogeneous, in addition, a quantitative analysis can be carried out, through meta-analysis [31].

This means that each study conditions to decide which subjects its implants, without any specific criteria, which makes it very difficult to know which of the implants have better mechanical behavior under certain conditions. This fact is evident in Tables 3 and 4 in which it is possible to observe the great variety of conditions used in the articles included in this review.

We used the Cochrane Handbook tool to assess the risk of bias in the studies, noting that in most domains, no data are given that give transparency to the studies. Generally, the criteria for randomization and allocation masking, and blinding of staff and data assessors are not indicated. Together with these detected defects and under recommendations some authors [70] in vitro studies should be treated to promote the quality of the tests: simple size calculation, meaningful difference between groups, sample preparation and handling, allocation sequence, randomization and blinding, statistical analysis.

The heterogeneity of data available in the scientific literature does not allow a meta-analysis in the field of in vitro fatigue and fracture of dental implants. As in the design of clinical trials in humans with the CONSORT (Consolidated Standards of Reporting Trials) guidelines [71], we consider it advisable to follow guidelines for in vitro studies such as the CRIS (Checklist for Reporting in vitro Studies) guidelines [70]. Also, define the criteria and conditions of applied loads (magnitude, angle, frequency, cycles ... ) and are contained in an ISO standard.

Nevertheless, we have found, in the present review that the internal connections [42,44], and those based on the morse taper system [34,39,49,72] show a better performance against resistance to fracture in the dental implant compared to the external connection [34,48]. Moreover, the results revealed that the implant and the abutment have better behavior if both materials are the same.

In addition, these studies assessed a range of materials, but the most frequently used materials are still in order of use, titanium and zirconium, with a behavior similar to fatigue.

\section{Conclusions}

The limitations found in this review do not allow us to report consistent evidence. The results suggest that the internal and morse connections are the best for resisting the fracture of the dental implants and the most commonly used materials are titanium and zirconium. However, it is necessary to unify criteria in the methodological design of this type of in vitro studies.

Author Contributions: R.R. developed the main part of the review, created the search strategy, selected the articles, performed the statistical analysis and wrote part of the paper. M.P.-P. selected the articles, evaluated the methodological quality of the studies and wrote part of the paper. A.J.R. evaluated the methodological quality of the studies. J.C.P.-F. provided critical analysis and interpretation of data. 
Acknowledgments: The authors received financial support of grants A-274 (Instradent Iberia ${ }^{\circledR}$ S.A., Alcobendas, Spain) and A-285 (Proclinic ${ }^{\circledR}$ S.A, Zaragoza, Spain).

Conflicts of Interest: The authors declare no conflict of interest.

\section{References}

1. Tian, K.; Chen, J.; Han, L.; Yang, J.; Huang, W.; Wu, D. Angled abutments result in increased or decreased stress on surrounding bone of single-unit dental implants: A finite element analysis. Med. Eng. Phys. 2012, 34, 1526-1531. [CrossRef] [PubMed]

2. Coray, R.; Zeltner, M.; Özcan, M. Fracture strength of implant abutments after fatigue testing: A systematic review and a meta-analysis. J. Mech. Behav. Biomed. Mater. 2016, 62, 333-346. [CrossRef] [PubMed]

3. Elias, C.N.; Fernandes, D.J.; Resende, C.R.S.; Roestel, J. Mechanical properties, surface morphology and stability of a modified commercially pure high strength titanium alloy for dental implants. Dent. Mater. 2015, 31, e1-e13. [CrossRef] [PubMed]

4. Osman, R.B.; Swain, M.V. A Critical Review of Dental Implant Materials with an Emphasis on Titanium versus Zirconia. Materials 2015, 8, 932-958. [CrossRef] [PubMed]

5. Ottria, L.; Lauritano, D.; Andreasi Bassi, M.; Palmieri, A.; Candotto, V.; Tagliabue, A.; Tettamanti, L. Mechanical, chemical and biological aspects of titanium and titanium alloys in implant dentistry. J. Biol. Regul. Homeost. Agents 2018, 32, 81-90. [PubMed]

6. Kirmanidou, Y.; Sidira, M.; Drosou, M.-E.; Bennani, V.; Bakopoulou, A.; Tsouknidas, A.; Michailidis, N.; Michalakis, K. New Ti-Alloys and Surface Modifications to Improve the Mechanical Properties and the Biological Response to Orthopedic and Dental Implants: A Review. Biomed Res. Int. 2016, 2016, 2908570. [CrossRef] [PubMed]

7. Kent, D.; Wang, G.; Dargusch, M. Effects of phase stability and processing on the mechanical properties of Ti-Nb based beta Ti alloys. J. Mech. Behav. Biomed. Mater. 2013, 28, 15-25. [CrossRef] [PubMed]

8. Hatamleh, M.M.; Wu, X.; Alnazzawi, A.; Watson, J.; Watts, D. Surface characteristics and biocompatibility of cranioplasty titanium implants following different surface treatments. Dent. Mater. 2018, 34, 676-683. [CrossRef] [PubMed]

9. Wennerberg, A. The importance of surface roughness for implant incorporation. Int. J. Mach. Tools Manuf. 1998, 38, 657-662. [CrossRef]

10. Komasa, S.; Taguchi, Y.; Nishida, H.; Tanaka, M.; Kawazoe, T. Bioactivity of nanostructure on titanium surface modified by chemical processing at room temperature. J. Prosthodont. Res. 2012, 56, 170-177. [CrossRef] [PubMed]

11. Kubasiewicz-Ross, P.; Dominiak, M.; Gedrange, T.; Botzenhart, U.U. Zirconium: The material of the future in modern implantology. Adv. Clin. Exp. Med. 2017, 26, 533-537. [CrossRef] [PubMed]

12. Freitas, G.; Hirata, R.; Bonfante, E.; Tovar, N.; Coelho, P. Survival Probability of Narrow and Standard-Diameter Implants with Different Implant-Abutment Connection Designs. Int. J. Prosthodont. 2016, 29, 179-185. [CrossRef] [PubMed]

13. Bartlett, D. Implants for life? A critical review of implant-supported restorations. J. Dent. 2007, 35, 768-772. [CrossRef] [PubMed]

14. Pardal-Pelaez, B.; Montero, J. Preload loss of abutment screws after dynamic fatigue in single implant-supported restorations. A systematic review. J. Clin. Exp. Dent. 2017, 9, e1355-e1361. [CrossRef] [PubMed]

15. Gehrke, S.A.; Delgado-Ruiz, R.A.; Prados Frutos, J.C.; Prados-Privado, M.; Dedavid, B.A.; Granero Marin, J.M.; Calvo Guirado, J.L. Misfit of Three Different Implant-Abutment Connections Before and After Cyclic Load Application: An In Vitro Study. Int. J. Oral Maxillofac. Implant. 2017, 32, 822-829. [CrossRef] [PubMed]

16. Prados-Privado, M.; Bea, J.A.; Rojo, R.; Gehrke, S.A.; Calvo-Guirado, J.L.; Prados-Frutos, J.C. A New Model to Study Fatigue in Dental Implants Based on Probabilistic Finite Elements and Cumulative Damage Model. Appl. Bionics Biomech. 2017, 2017. [CrossRef] [PubMed]

17. Schmitt, C.M.; Nogueira-Filho, G.; Tenenbaum, H.C.; Lai, J.Y.; Brito, C.; Döring, H.; Nonhoff, J. Performance of conical abutment (Morse Taper) connection implants: A systematic review. J. Biomed. Mater. Res. Part A 2014, 102, 552-574. [CrossRef] [PubMed] 
18. Sailer, I.; Sailer, T.; Stawarczyk, B.; Jung, R.E.; Hämmerle, C.H.F. In vitro study of the influence of the type of connection on the fracture load of zirconia abutments with internal and external implant-abutment connections. Int. J. Oral Maxillofac. Implant. 2009, 24, 850-858. [CrossRef]

19. Kitagawa, T.; Tanimoto, Y.; Odaki, M.; Nemoto, K.; Aida, M. Influence of implant/abutment joint designs on abutment screw loosening in a dental implant system. J. Biomed. Mater. Res. Part B Appl. Biomater. 2005, 75B, 457-463. [CrossRef] [PubMed]

20. Dittmer, M.P.; Dittmer, S.; Borchers, L.; Kohorst, P.; Stiesch, M. Influence of the interface design on the yield force of the implant-abutment complex before and after cyclic mechanical loading. J. Prosthodont. Res. 2012, 56, 19-24. [CrossRef] [PubMed]

21. Ritter, J.E. Critique of test methods for lifetime predictions. Dent. Mater. 1995, 11, 147-151. [CrossRef]

22. Marx, R.; Jungwirth, F.; Walter, P.-O. Threshold intensity factors as lower boundaries for crack propagation in ceramics. Biomed. Eng. Online 2004, 3, 41. [CrossRef] [PubMed]

23. Alqahtani, F.; Flinton, R. Postfatigue fracture resistance of modified prefabricated zirconia implant abutments. J. Prosthet. Dent. 2014, 112, 299-305. [CrossRef] [PubMed]

24. Organization, I.S. ISO 14801: Dentistry—Implants—Dynamic Fatigue Test for Endosseous Dental Implants; ISO: Geneve, Switzerland, 2007.

25. Marchetti, E.; Ratta, S.; Mummolo, S.; Tecco, S.; Pecci, R.; Bedini, R.; Marzo, G. Mechanical Reliability Evaluation of an Oral Implant-Abutment System According to UNI EN ISO 14801 Fatigue Test Protocol. Implant Dent. 2016, 25, 613-618. [CrossRef] [PubMed]

26. Lee, C.K.; Karl, M.; Kelly, J.R. Evaluation of test protocol variables for dental implant fatigue research. Dent. Mater. 2009, 25, 1419-1425. [CrossRef] [PubMed]

27. Snauwaert, K.; Duyck, J.; van Steenberghe, D.; Quirynen, M.; Naert, I. Time dependent failure rate and marginal bone loss of implant supported prostheses: A 15-year follow-up study. Clin. Oral Investig. 2000, 4, 0013-0020. [CrossRef]

28. Hasan, I.; Bourauel, C.; Mundt, T.; Stark, H.; Heinemann, F. Biomechanics and load resistance of small-diameter and mini dental implants: A review of literature. Biomed. Tech. Eng. 2014, 59, 1-5. [CrossRef] [PubMed]

29. Moher, D.; Altman, D.G.; Liberati, A.; Tetzlaff, J. PRISMA statement. Epidemiology 2011, 22, 128. [CrossRef] [PubMed]

30. Centre for Rewies and Dissemination, University of York. Systematic Reviews: CRD Guidance for Undertaking Reviews in Health Care; University of York: York, UK, 2009.

31. Higgins, J.P.T.; Altman, D.G. Assessing risk of bias in included studies. In Cochrane Handbook for Systematic Reviews of Interventions; Higgins, J.P.T., Green, S., Eds.; Wiley: Hoboken, NJ, USA, 2008; pp. 187-241.

32. Landis, J.R.; Koch, G.G. The measurement of observer agreement for categorical data. Biometrics 1977, 33, 159-174. [CrossRef] [PubMed]

33. Balfour, A.; O'Brien, G.R. Comparative study of antirotational single tooth abutments. J. Prosthet. Dent. 1995, 73, 36-43. [CrossRef]

34. Khraisat, A.; Stegaroiu, R.; Nomura, S.; Miyakawa, O. Fatigue resistance of two implant/abutment joint designs. J. Prosthet. Dent. 2002, 88, 604-610. [CrossRef] [PubMed]

35. Cehreli, M.C.; Akca, K.; Iplikcioglu, H.; Sahin, S. Dynamic fatigue resistance of implant-abutment junction in an internally notched morse-taper oral implant: Influence of abutment design. Clin. Oral Implant. Res. 2004, 15, 459-465. [CrossRef] [PubMed]

36. Butz, F.; Heydecke, G.; Okutan, M.; Strub, J.R. Survival rate, fracture strength and failure mode of ceramic implant abutments after chewing simulation. J. Oral Rehabil. 2005, 32, 838-843. [CrossRef] [PubMed]

37. Gehrke, P.; Dhom, G.; Brunner, J.; Wolf, D.; Degidi, M.; Piattelli, A. Zirconium implant abutments: Fracture strength and influence of cyclic loading on retaining-screw loosening. Quintessence Int. 2006, 37, 19-26. [PubMed]

38. Kohal, R.-J.; Finke, H.C.; Klaus, G. Stability of prototype two-piece zirconia and titanium implants after artificial aging: An in vitro pilot study. Clin. Implant Dent. Relat. Res. 2009, 11, 323-329. [CrossRef] [PubMed]

39. Scarano, A.; Sacco, M.L.; Di Iorio, D.; Amoruso, M.; Mancino, C. Valutazione della resistenza a fatica ciclica di una connessione impianto-abutment cone morse e avvitata. Ital. Oral Surg. 2010, 9, 173-179. [CrossRef] 
40. Magne, P.; Oderich, E.; Boff, L.L.; Cardoso, A.C.; Belser, U.C. Fatigue resistance and failure mode of CAD/CAM composite resin implant abutments restored with type III composite resin and porcelain veneers. Clin. Oral Implant. Res. 2011, 22, 1275-1281. [CrossRef] [PubMed]

41. Seetoh, Y.L.; Tan, K.B.; Chua, E.K.; Quek, H.C.; Nicholls, J.I. Load fatigue performance of conical implant-abutment connections. Int. J. Oral Maxillofac. Implant. 2011, 26, 797-806.

42. Stimmelmayr, M.; Edelhoff, D.; Güth, J.-F.; Erdelt, K.; Happe, A.; Beuer, F. Wear at the titanium-titanium and the titanium-zirconia implant-abutment interface: A comparative in vitro study. Dent. Mater. 2012, 28, 1215-1220. [CrossRef] [PubMed]

43. Foong, J.K.W.; Judge, R.B.; Palamara, J.E.; Swain, M.V. Fracture resistance of titanium and zirconia abutments: An in vitro study. J. Prosthet. Dent. 2013, 109, 304-312. [CrossRef]

44. Pintinha, M.; Camarini, E.T.; Sábio, S.; Pereira, J.R. Effect of mechanical loading on the removal torque of different types of tapered connection abutments for dental implants. J. Prosthet. Dent. 2013, 110, 383-388. [CrossRef] [PubMed]

45. Marchetti, E.; Ratta, S.; Mummolo, S.; Tecco, S.; Pecci, R.; Bedini, R.; Marzo, G. Evaluation of an Endosseous Oral Implant System According to UNI EN ISO 14801 Fatigue Test Protocol. Implant Dent. 2014, 23, 665-671. [CrossRef] [PubMed]

46. Rosentritt, M.; Hagemann, A.; Hahnel, S.; Behr, M.; Preis, V. In vitro performance of zirconia and titanium implant/abutment systems for anterior application. J. Dent. 2014, 42, 1019-1026. [CrossRef] [PubMed]

47. Mitsias, M.E.; Thompson, V.P.; Pines, M.; Silva, N.R.F.A. Reliability and failure modes of two Y-TZP abutment designs. Int. J. Prosthodont. 2015, 28, 75-78. [CrossRef] [PubMed]

48. Spies, B.C.; Nold, J.; Vach, K.; Kohal, R.-J. Two-piece zirconia oral implants withstand masticatory loads: An investigation in the artificial mouth. J. Mech. Behav. Biomed. Mater. 2016, 53, 1-10. [CrossRef] [PubMed]

49. Guilherme, N.M.; Chung, K.-H.; Flinn, B.D.; Zheng, C.; Raigrodski, A.J. Assessment of reliability of CAD-CAM tooth-colored implant custom abutments. J. Prosthet. Dent. 2016, 116, 206-213. [CrossRef] [PubMed]

50. Preis, V.; Kammermeier, A.; Handel, G.; Rosentritt, M. In vitro performance of two-piece zirconia implant systems for anterior application. Dent. Mater. 2016, 32, 765-774. [CrossRef] [PubMed]

51. Sahin, S.; Cehreli, M.C.; Yalcin, E. The influence of functional forces on the biomechanics of implant-supported prostheses-A review. J. Dent. 2002, 30, 271-282. [CrossRef]

52. Flanagan, D. Bite force and dental implant treatment: A short review. Med. Devices 2017, 10, 141-148. [CrossRef] [PubMed]

53. Chrcanovic, B.R.; Kisch, J.; Albrektsson, T.; Wennerberg, A. Factors Influencing Early Dental Implant Failures. J. Dent. Res. 2016, 95, 995-1002. [CrossRef] [PubMed]

54. Hoyer, S.A.; Stanford, C.M.; Buranadham, S.; Fridrich, T.; Wagner, J.; Gratton, D. Dynamic fatigue properties of the dental implant-abutment interface: Joint opening in wide-diameter versus standard-diameter hex-type implants. J. Prosthet. Dent. 2001, 85, 599-607. [CrossRef] [PubMed]

55. Piattelli, A.; Scarano, A.; Piattelli, M.; Vaia, E.; Matarasso, S. Hollow implants retrieved for fracture: A light and scanning electron microscope analysis of 4 cases. J. Periodontol. 1998, 69, 185-189. [CrossRef] [PubMed]

56. Tolman, D.E.; Laney, W.R. Tissue-integrated prosthesis complications. Int. J. Oral Maxillofac. Implants 1992, 7 , 477-484. [CrossRef] [PubMed]

57. Steinebrunner, L.; Wolfart, S.; Ludwig, K.; Kern, M. Implant-abutment interface design affects fatigue and fracture strength of implants. Clin. Oral Implant. Res. 2008, 19, 1276-1284. [CrossRef] [PubMed]

58. Pita, M.S.; Anchieta, R.B.; Barao, V.A.; Garcia, I.R., Jr.; Pedrazzi, V.; Assuncao, W.G. Prosthetic platforms in implant dentistry. J. Craniofac. Surg. 2011, 22, 2327-2331. [CrossRef] [PubMed]

59. Gaviria, L.; Salcido, J.P.; Guda, T.; Ong, J.L. Current trends in dental implants. J. Korean Assoc. Oral Maxillofac. Surg. 2014, 40, 50-60. [CrossRef] [PubMed]

60. Finger, I.M.; Castellon, P.; Block, M.; Elian, N. The evolution of external and internal implant/abutment connections. Pract. Proced. Aesthet. Dent. 2003, 15, 625-632. [PubMed]

61. Binon, P.P. Implants and components: Entering the new millennium. Int. J. Oral Maxillofac. Implant. 2000, 15, 76-94.

62. Gracis, S.; Michalakis, K.; Vigolo, P.; Vult von Steyern, P.; Zwahlen, M.; Sailer, I. Internal vs. external connections for abutments/reconstructions: A systematic review. Clin. Oral Implant. Res. 2012, 23 (Suppl. 6), 202-216. [CrossRef] [PubMed] 
63. Macedo, J.P.; Pereira, J.; Vahey, B.R.; Henriques, B.; Benfatti, C.A.; Magini, R.S.; Lopez-Lopez, J.; Souza, J.C. Morse taper dental implants and platform switching: The new paradigm in oral implantology. Eur. J. Dent. 2016, 10, 148-154. [CrossRef] [PubMed]

64. Cheng, Y.C.; Lin, D.H.; Jiang, C.P.; Lee, S.Y. Design improvement and dynamic finite element analysis of novel ITI dental implant under dynamic chewing loads. Biomed. Mater. Eng. 2015, 26 (Suppl. 1), S555-S561. [CrossRef] [PubMed]

65. Prados-Privado, M.; Prados-Frutos, J.C.; Calvo-Guirado, J.L.; Bea, J.A. A random fatigue of mechanize titanium abutment studied with Markoff chain and stochastic finite element formulation. Comput. Methods Biomech. Biomed. Eng. 2016, 19, 1583-1591. [CrossRef] [PubMed]

66. Anchieta, R.B.; Machado, L.S.; Hirata, R.; Bonfante, E.A.; Coelho, P.G. Platform-Switching for Cemented Versus Screwed Fixed Dental Prostheses: Reliability and Failure Modes: An In Vitro Study. Clin. Implant Dent. Relat. Res. 2016, 18, 830-839. [CrossRef] [PubMed]

67. Bordin, D.; Bergamo, E.T.P.; Fardin, V.P.; Coelho, P.G.; Bonfante, E.A. Fracture strength and probability of survival of narrow and extra-narrow dental implants after fatigue testing: In vitro and in silico analysis. J. Mech. Behav. Biomed. Mater. 2017, 71, 244-249. [CrossRef] [PubMed]

68. Kim, J.-W.; Covel, N.S.; Guess, P.C.; Rekow, E.D.; Zhang, Y. Concerns of hydrothermal degradation in CAD/CAM zirconia. J. Dent. Res. 2010, 89, 91-95. [CrossRef] [PubMed]

69. Kawai, Y.; Uo, M.; Wang, Y.; Kono, S.; Ohnuki, S.; Watari, F. Phase transformation of zirconia ceramics by hydrothermal degradation. Dent. Mater. J. 2011, 30, 286-292. [CrossRef] [PubMed]

70. Krithikadatta, J.; Gopikrishna, V.; Datta, M. CRIS Guidelines (Checklist for Reporting In-vitro Studies): A concept note on the need for standardized guidelines for improving quality and transparency in reporting in-vitro studies in experimental dental research. J. Conserv. Dent. 2014, 17, 301-304. [CrossRef] [PubMed]

71. Palmas, W. The CONSORT guidelines for noninferiority trials should be updated to go beyond the absolute risk difference. J. Clin. Epidemiol. 2017, 83, 6-7. [CrossRef] [PubMed]

72. Machado, L.S.; Bonfante, E.A.; Anchieta, R.B.; Yamaguchi, S.; Coelho, P.G. Implant-abutment connection designs for anterior crowns: Reliability and failure modes. Implant Dent. 2013, 22, 540-545. [CrossRef] [PubMed] 